\title{
Blood glucose, acid-base and electrolyte changes during loading doses of alpha2-adrenergic agonists followed by constant rate infusions in horses
}

\author{
Ringer, Simone K ; Schwarzwald, Colin C ; Portier, K ; Mauch, J ; Ritter, A ; Bettschart-Wolfensberger, Regula
}

\begin{abstract}
The aim of the present study was to investigate changes in blood glucose concentration ([Glu]B), acidbase status and electrolyte concentrations during constant rate infusions (CRI) of two alpha2-adrenergic agonists in seven horses treated in a blinded, randomised, crossover design with xylazine or romifidine. An intravenous (IV) bolus of xylazine $(1 \mathrm{mg} / \mathrm{kg})$ or romifidine $(80 \mu \mathrm{g} / \mathrm{kg})$ was administered followed by an IV CRI of xylazine $(0.69 \mathrm{mg} / \mathrm{kg} / \mathrm{h})$ or romifidine $(30 \mu \mathrm{g} / \mathrm{kg} / \mathrm{h})$ for $2 \mathrm{~h}$. Blood samples were collected from the pulmonary artery before and after loading doses, during the CRI, and for $1 \mathrm{~h}$ after discontinuing drugs. Blood glucose, base excess (BE), $\mathrm{pH}$, partial pressure of carbon dioxide $\left(\mathrm{Pv}^{-} \mathrm{CO} 2\right)$, strong ion difference (SIDest) and bicarbonate concentration ( [Formula: see text] ) increased significantly during the CRI with both alpha2-adrenergic agonists. Chloride concentration ([Cl-]B) and anion-gap (AG) decreased significantly compared to baseline. The decrease in sodium concentration $([\mathrm{Na}+] \mathrm{B})$ was only significant with xylazine. From $1 \mathrm{~h}$ after starting the CRI onwards, [Glu]B was significantly higher with romifidine compared to xylazine. Except [Glu]B, SIDest, and $\mathrm{Pv}^{-} \mathrm{CO} 2$, all variables returned to normal values $1 \mathrm{~h}$ after discontinuing xylazine. After stopping romifidine, all variables except $\mathrm{pH}$ remained altered for at least $1 \mathrm{~h}$. It was concluded that loading doses of alpha2-adrenergic agonists followed by CRIs produce [Glu]B, acid-base and electrolyte changes. The clinical significance of the reported changes remains to be investigated and absolute values should be interpreted with caution, as fluid boli were used for cardiac output measurements, but may become important during prolonged infusion and in critically ill patients.
\end{abstract}

DOI: https://doi.org/10.1016/j.tvjl.2013.09.063

Posted at the Zurich Open Repository and Archive, University of Zurich ZORA URL: https://doi.org/10.5167/uzh-85074

Journal Article

Originally published at:

Ringer, Simone K; Schwarzwald, Colin C; Portier, K; Mauch, J; Ritter, A; Bettschart-Wolfensberger, Regula (2013). Blood glucose, acid-base and electrolyte changes during loading doses of alpha2-adrenergic agonists followed by constant rate infusions in horses. Veterinary Journal, 198(3):684-689.

DOI: https://doi.org/10.1016/j.tvjl.2013.09.063 


\title{
Blood glucose, acid-base and electrolyte changes during loading doses of alpha $_{2}$-adrenergic agonists followed by constant rate infusions in horses
}

\author{
S.K. Ringer ${ }^{\mathrm{a}, *}$, C.C. Schwarzwald ${ }^{\mathrm{b}}$, K. Portier ${ }^{\mathrm{c}}$, J. Mauch ${ }^{\mathrm{d}, \mathrm{e}}$, A. Ritter ${ }^{\mathrm{a}}$, R. Bettschart-Wolfensberger ${ }^{\mathrm{a}}$ \\ a Equine Department, Anaesthesiology Section, Vetsuisse Faculty, University of Zurich, Zurich, Switzerland \\ ${ }^{\mathrm{b}}$ Equine Department, Clinic for Equine Internal Medicine, Vetsuisse Faculty, University of Zurich, Zurich, Switzerland \\ ' Equine Department, Anaesthesiology, VetAgro Sup (Veterinary Campus of Lyon), Marcy L'Etoile, France \\ ${ }^{\mathrm{d}}$ Department of Anaesthesia and Perioperative Medicine, Kantonsspital Aarau, Aarau, Switzerland \\ e Department of Anaesthesia, University Children's Hospital, Zurich, Switzerland
}

\section{A R T I C L E I N F O}

\section{Article history:}

Accepted 29 September 2013

Available online $\mathrm{xxxx}$

\section{Keywords:}

Acid-base

Electrolytes

Glucose

Romifidine

Xylazine

\begin{abstract}
A B S T R A C T
The aim of the present study was to investigate changes in blood glucose concentration $\left([\mathrm{Glu}]_{\mathrm{B}}\right)$, acidbase status and electrolyte concentrations during constant rate infusions (CRI) of two alpha $_{2}$-adrenergic agonists in seven horses treated in a blinded, randomised, crossover design with xylazine or romifidine. An intravenous (IV) bolus of xylazine ( $1 \mathrm{mg} / \mathrm{kg})$ or romifidine $(80 \mu \mathrm{g} / \mathrm{kg})$ was administered followed by an IV CRI of xylazine $(0.69 \mathrm{mg} / \mathrm{kg} / \mathrm{h})$ or romifidine $(30 \mu \mathrm{g} / \mathrm{kg} / \mathrm{h})$ for $2 \mathrm{~h}$. Blood samples were collected from the pulmonary artery before and after loading doses, during the CRI, and for $1 \mathrm{~h}$ after discontinuing drugs.

Blood glucose, base excess (BE), $\mathrm{pH}$, partial pressure of carbon dioxide $\left(\mathrm{P}_{\overline{\mathrm{v}}} \mathrm{CO}_{2}\right)$, strong ion difference $\left(\mathrm{SID}_{\mathrm{est}}\right)$ and bicarbonate concentration $\left(\left[\mathrm{HCO}_{3}^{-} \mathrm{std}_{\mathrm{B}}\right)\right.$ increased significantly during the CRI with both alpha ${ }_{2}$-adrenergic agonists. Chloride concentration $\left(\left[\mathrm{Cl}^{-}\right]_{\mathrm{B}}\right)$ and anion-gap (AG) decreased significantly compared to baseline. The decrease in sodium concentration $\left(\left[\mathrm{Na}^{+}\right]_{\mathrm{B}}\right)$ was only significant with xylazine. From $1 \mathrm{~h}$ after starting the CRI onwards, $[\mathrm{Glu}]_{\mathrm{B}}$ was significantly higher with romifidine compared to xylazine. Except $[\mathrm{Glu}]_{\mathrm{B}}, \mathrm{SID}_{\mathrm{est}}$, and $\mathrm{P}_{\mathrm{v}} \mathrm{CO}_{2}$, all variables returned to normal values $1 \mathrm{~h}$ after discontinuing xylazine. After stopping romifidine, all variables except $\mathrm{pH}$ remained altered for at least $1 \mathrm{~h}$.

It was concluded that loading doses of alpha ${ }_{2}$-adrenergic agonists followed by CRIs produce $[\mathrm{Glu}]_{\mathrm{B}}$, acid-base and electrolyte changes. The clinical significance of the reported changes remains to be investigated and absolute values should be interpreted with caution, as fluid boli were used for cardiac output measurements, but may become important during prolonged infusion and in critically ill patients.
\end{abstract}

(c) 2013 Elsevier Ltd. All rights reserved.

\section{Introduction}

Alpha 2 -adrenergic agonists are routinely used for sedation and analgesia in veterinary medicine (Dart, 1999) and administration as an intravenous (IV) constant rate infusion (CRI) is becoming more frequent (Lamont et al., 2012; Ringer, 2012). The main advantages of alpha ${ }_{2}$-adrenergic agonists in humans are the potent sedative and analgesic effects with minimal respiratory depression and less postoperative delirium compared to other drugs (Hoy and Keating, 2011). In human intensive care units (ICUs) interest in CRI of alpha ${ }_{2}$-adrenergic agonists is increasing (Tan and Ho, 2010; Hoy and Keating, 2011). This tendency is also observed in veterinary critical care patients (Posner and Burns, 2009).

Concerns regarding alpha ${ }_{2}$-adrenergic agonists mainly reflect their cardiovascular (CV) effects (England and Clarke, 1996; Murrell and Hellebrekers, 2005; Tan and Ho, 2010), and many studies

\footnotetext{
* Corresponding author. Tel.: +41446358499.

E-mail address: sringer@vetclinics.uzh.ch (S.K. Ringer).
}

have been designed to examine the CV effects of alpha ${ }_{2}$-adrenergic agonist CRIs in horses (Bettschart-Wolfensberger et al., 1999; Ringer et al., 2013a). However, the use of alpha ${ }_{2}$-adrenergic agonists is also associated with other side effects that might be less obvious, but may have important consequences, especially in critically ill patients. For example, hyperglycaemia is associated with worse outcomes in proportion to the elevations in blood glucose concentration $\left([\mathrm{Glu}]_{B}\right)$ in human medicine (Klonoff, 2011). Hyperglycaemia is also associated with diuresis, which has been described following single doses of alpha $_{2}$-adrenergic agonists in horses (England and Clarke, 1996) and other species (Ambrisko and Hikasa, 2002; Kanda and Hikasa, 2008; Talukder and Hikasa, 2009; Murahata and Hikasa, 2011).

Despite the increasing use of alpha $a_{2}$-adrenergic agonists, including in critically ill animals (Posner and Burns, 2009), changes in $[\mathrm{Glu}]_{\mathrm{B}}$, electrolyte concentrations and acid-base status during CRIs of alpha $a_{2}$-adrenergic agonists remain insufficiently studied. Additionally, the different alpha ${ }_{2}$-adrenergic agonists used as a CRI have not been compared regarding their effects on $[\mathrm{Glu}]_{B}$, 
electrolytes and acid-base status. Xylazine and romifidine are both registered alpha $a_{2}$-adrenergic agonists commonly used in equine clinical practice. Romifidine is more alpha ${ }_{2}$ receptor-selective than xylazine or detomidine, but less than medetomidine (Muir, 2009). The aim of the present study was to investigate the effects of xylazine and romifidine CRIs on [Glu $]_{B}$, acid-base balance and electrolytes in horses, and to compare the two drugs.

\section{Materials and methods}

The study was approved by the Ethical Committee of the National Veterinary School of Lyon (0807, 13 May 2008) and was performed using blood samples obtained during a cardiovascular study reported elsewhere (Ringer et al., 2013a).

For the concurrent cardiovascular study, seven research horses (six French Standardbreds and one French Saddlebred; $8.7 \pm 1.75$ years; $515.2 \pm 52.96 \mathrm{~kg}$ ) were catheterised with Swan-Ganz thermodilution catheters placed in the pulmonary arteries. The catheters were advanced through $8.5 \mathrm{~F}$ introducer sheaths (Intro-flex, Edwards Lifesciences) that had been previously placed in the jugular vein.

After catheterisation, two baseline blood samples (B1, B2) were collected $10 \mathrm{~min}$ apart from the pulmonary artery. Blood samples were collected anaerobically into blood gas syringes (BD A-Line, BD Diagnostics) and immediately analysed using a point-of-care blood gas system including a co-oximeter (Rapidpoint 400, Siemens Medical Solutions Diagnostics).

Blood gases were analysed at $37^{\circ} \mathrm{C}$ without correcting for the horses' temperature. The blood gas analyser measured $\mathrm{pH}$, partial pressure of carbon dioxide $\left(\mathrm{P}_{\bar{v}} \mathrm{CO}_{2}\right),[\mathrm{Glu}]_{\mathrm{B}}$, and blood electrolyte concentrations (sodium $\left[\mathrm{Na}^{+}\right]_{\mathrm{B}}$, chloride $\left[\mathrm{Cl}^{-}\right]_{\mathrm{B}}$, and potassium $\left[\mathrm{K}^{+}\right]_{\mathrm{B}}$ ). The anion gap $(\mathrm{AG})$, standard bicarbonate concentration $\left[\mathrm{HCO}_{3}^{-}{ }_{\text {std }}\right]_{\mathrm{B}}$, and base excess of the extracellular compartment $\left(\mathrm{BE}_{\mathrm{ecf}}\right)$ were calculated automatically by the analyser. Strong ion difference was estimated ( $\left.\operatorname{SID}_{\text {est }}\right)$ by manual calculation using the formula: $\operatorname{SID}_{\mathrm{est}}=\left[\mathrm{Na}^{+}\right]_{\mathrm{B}}-\left[\mathrm{Cl}^{-}\right]_{\mathrm{B}}$. Preliminary reference values for the blood gas analyser were determined including 15 healthy horses and were defined as means \pm 2 SD.

Horses were treated in a blinded, randomised, crossover design with xylazine or romifidine. A 16-day washout period was allowed between treatments. After baseline measurements, horses were sedated with xylazine (Xylasol, Dr. E. Graeub) $(1 \mathrm{mg} / \mathrm{kg}$ ) or romifidine (Sedivet, Boehringer Ingelheim) $(80 \mu \mathrm{g} / \mathrm{kg})$ given IV over 3 min by manual injection through the side arm of one of the introducer sheaths. The start of the loading dose administration was time point 0 . Loading doses were followed by xylazine $(0.69 \mathrm{mg} / \mathrm{kg} / \mathrm{h})$ or romifidine $(30 \mu \mathrm{g} / \mathrm{kg} / \mathrm{h})$ CRI for $2 \mathrm{~h}$ (time points 3-123 min). The CRIs were delivered by infusion pumps (Syramed $\mu \mathrm{SP} 6000$, Arcomed). Drugs were diluted in $0.9 \%$ saline (Chlorure de Sodium $0.9 \%$; Braun Medical) by an unblinded person, so that equal volumes ( $50 \mathrm{~mL}$ loading dose, $25 \mathrm{~mL} / \mathrm{h} \mathrm{CRI}$ ) were administered in both treatments.

Beside the CRIs containing alpha ${ }_{2}$-adrenergic agonists in $0.9 \% \mathrm{NaCl}$, the horses did not receive any oral or IV fluids throughout the duration of the study, with the exception of repeated boluses of ice-cold fluids (5\% glucose [Braun Medical] in five horses, $0.9 \% \mathrm{NaCl}$ in two horses) used for cardiac output measurements by thermodilution conducted within the concurrent CV study. Administered bolus doses resulted in average (mean $\pm \mathrm{SD}$ ) $5 \%$ glucose doses per hour of $1.3 \pm 0.61 \mathrm{~mL}$ / $\mathrm{kg} / \mathrm{h}$ (xylazine treatment) and $1.3 \pm 0.65 \mathrm{~mL} / \mathrm{kg} / \mathrm{h}$ (romifidine treatment). The average $0.9 \% \mathrm{NaCl}$ dose was $1.2 \pm 0.64 \mathrm{~mL} / \mathrm{kg} / \mathrm{h}$ (xylazine) and $1.4 \pm 0.48 \mathrm{~mL} / \mathrm{kg} / \mathrm{h}$ (romifidine). Cardiac output measurements were done at each time point, always after blood collection. The horses received the same type of fluid during both treatments.

Blood analyses were repeated immediately after finishing loading dose administration ( $3 \mathrm{~min}$ ) and thereafter every 10 min during the first hour of CRI $(13,23,33$, 43, 53, $63 \mathrm{~min}$ ) and every $15 \mathrm{~min}$ during the second hour $(78,93,108,123 \mathrm{~min})$. The CRIs were discontinued after $2 \mathrm{~h}$ (time point $123 \mathrm{~min}$ ) and data were collected every $15 \mathrm{~min}$ for an additional hour $(138,153,168$, and $183 \mathrm{~min})$.

\section{Statistical methods}

As there was no difference in results when the horses receiving glucose for cardiac output measurements were analysed separately from the ones receiving saline, data of all seven horses were pooled for statistical analysis. Statistical analysis was performed using SigmaStat 3.5 (Systat Software). Homogeneity of variances was assessed by graphical display of the data and validity of the normality assumption was confirmed by assessment of normal probability plots of the residuals. Twoway repeated measures ANOVA (two within factors) followed by a Holm-Sidak test for multiple comparisons versus a control (time point B1) was used to compare the two treatments and to study changes over time compared to baseline. The level of significance was set at $P<0.05$.

\section{Results}

A significant increase in $[\mathrm{Glu}]_{\mathrm{B}}$ was observed during both alpha $_{2}$-adrenergic agonist infusions (Treatment, $P=0.001$; Time,
$P<0.001$; Treatment $\times$ Time, $P<0.001)$ (Fig. 1$)$. The increase was more pronounced with romifidine compared to xylazine. An increase in $[\mathrm{Glu}]_{\mathrm{B}}$ was also observed in horses receiving $0.9 \% \mathrm{NaCl}$ instead of $5 \%$ glucose for cardiac output measurements (Fig. 1).

Significant changes in $\mathrm{pH}$ were seen over time and between treatments (Treatment, $P=0.007$; Time, $P<0.001$; Treatment $\times$ Time, $P=0.330$ ) (Fig. 2). There was a significant increase in $\mathrm{pH}$ with both alpha ${ }_{2}$-adrenergic agonists. Overall and already at baseline, $\mathrm{pH}$ was significantly higher with romifidine compared to xylazine. Also, a significant increase in $\mathrm{BE}_{\mathrm{ecf}}$ (Treatment, $P=0.156$; Time, $P<0.001$; Treatment $\times$ Time, $P<0.001)$ and $\left[\mathrm{HCO}_{3 \mathrm{std}}^{-}\right]_{\mathrm{B}} \quad$ (Treatment, $P=0.057$; Time, $P<0.001$; Treatment $\times$ Time, $P<0.001$ ) was observed during both alpha ${ }_{2}$-adrenergic agonists (Fig. 2). After discontinuing CRIs, the effects on $\mathrm{BE}_{\mathrm{ecf}}$ and $\left[\mathrm{HCO}_{3}^{-} \text {std }\right]_{B}$ were longer lasting with romifidine compared to xylazine. During drug administration, a progressive, significant increase in $\mathrm{P}_{\bar{v}} \mathrm{CO}_{2}$ (Treatment, $P=0.40$; Time, $P<0.001$; Treatment $\times$ Time, $P=0.008$ ) was seen with both treatments (Fig. 2). With romifidine the $\mathrm{P}_{\bar{v}} \mathrm{CO}_{2}$ remained increased $1 \mathrm{~h}$ after discontinuing CRI.

With both alpha ${ }_{2}$-adrenergic agonists a significant decrease in $\left[\mathrm{Cl}^{-}\right]_{\mathrm{B}}$ was observed (Treatment, $P=0.080$; Time, $P<0.001$; Treatment $\times$ Time, $P<0.001$ ) (Fig. 3). Effects on $\left[\mathrm{Cl}^{-}\right]_{\mathrm{B}}$ were more prolonged with romifidine. A significant decrease in $\left[\mathrm{Na}^{+}\right]_{\mathrm{B}}$ was detected over time for xylazine, but not for romifidine (Treatment, $P=0.021$; Time, $P=0.056$; Treatment $\times$ Time, $P=0.031$ ) (Fig. 3). Already at baseline, $\left[\mathrm{Na}^{+}\right]_{\mathrm{B}}$ values were significantly lower with romifidine compared to xylazine, and remained significantly lower at different measurement points. No significant changes over time or between treatments were seen for $\left[\mathrm{K}^{+}\right]_{\mathrm{B}}$ (Treatment, $P=0.080$; Time, $P=0.951$; Treatment $\times$ Time, $P=0.216$ ) (Fig. 3 ).

There were no significant differences in $\operatorname{SID}_{\text {est }}$ between treat-

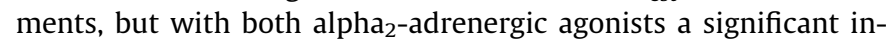
crease over time was observed (Treatment, $P=0.594$; Time, $P<0.001$; Treatment $\times$ Time, $P=0.057$ ) (Fig. 4). With xylazine there was a significant decrease in AG during drug administration, while with romifidine a decrease in AG was only observed $1 \mathrm{~h}$ after drug discontinuation (Treatment, $P=0.845$; Time, $P<0.001$; Treatment $\times$ Time, $P=0.002$ ) (Fig. 4). A significantly lower AG was

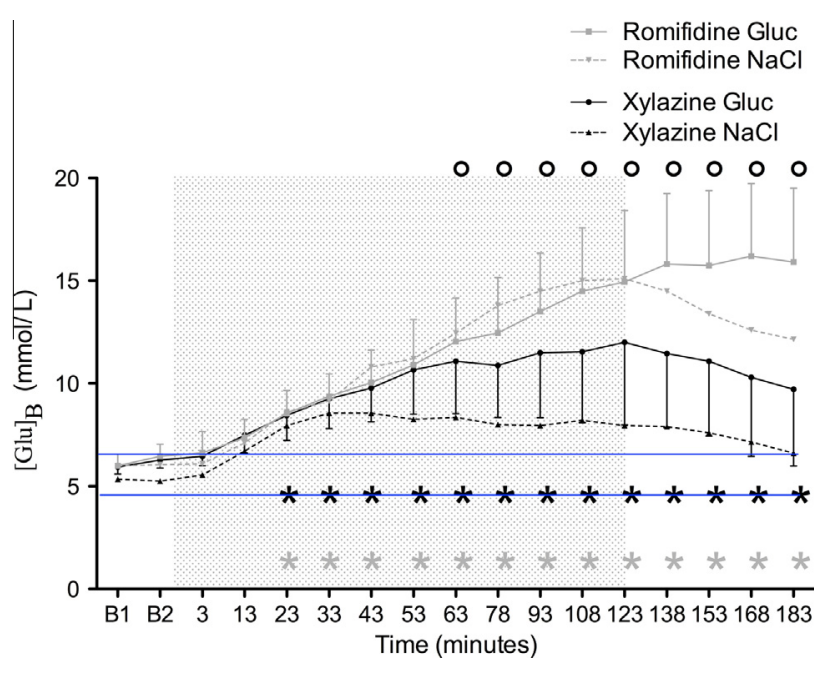

Fig. 1. Blood glucose concentration $\left([\mathrm{Glu}]_{\mathrm{B}}\right.$ : mean $\left.\pm \mathrm{SD}\right)$ measured before loading doses of xylazine and romifidine (B1, B2), immediately after loading dose administration ( $3 \mathrm{~min}$ ), during $2 \mathrm{~h}$ of CRI (3-123 min), and for $1 \mathrm{~h}$ after discontinuing CRI (123-183 min). Five horses received 5\% glucose (continuous lines) and two received $0.9 \% \mathrm{NaCl}$ (dashed lines) for cardiac output measurements. Dotted area shows drug administration time. * Significant difference (Holm-Sidak, $P<0.05)$ compared to the baseline (B1) of the same treatment. $\bigcirc$ Significant difference (Holm-Sidak, $P<0.05$ ) between treatments Blue lines represent (mean $\pm 2 \mathrm{SD}$ ) values obtained in 15 healthy horses. 

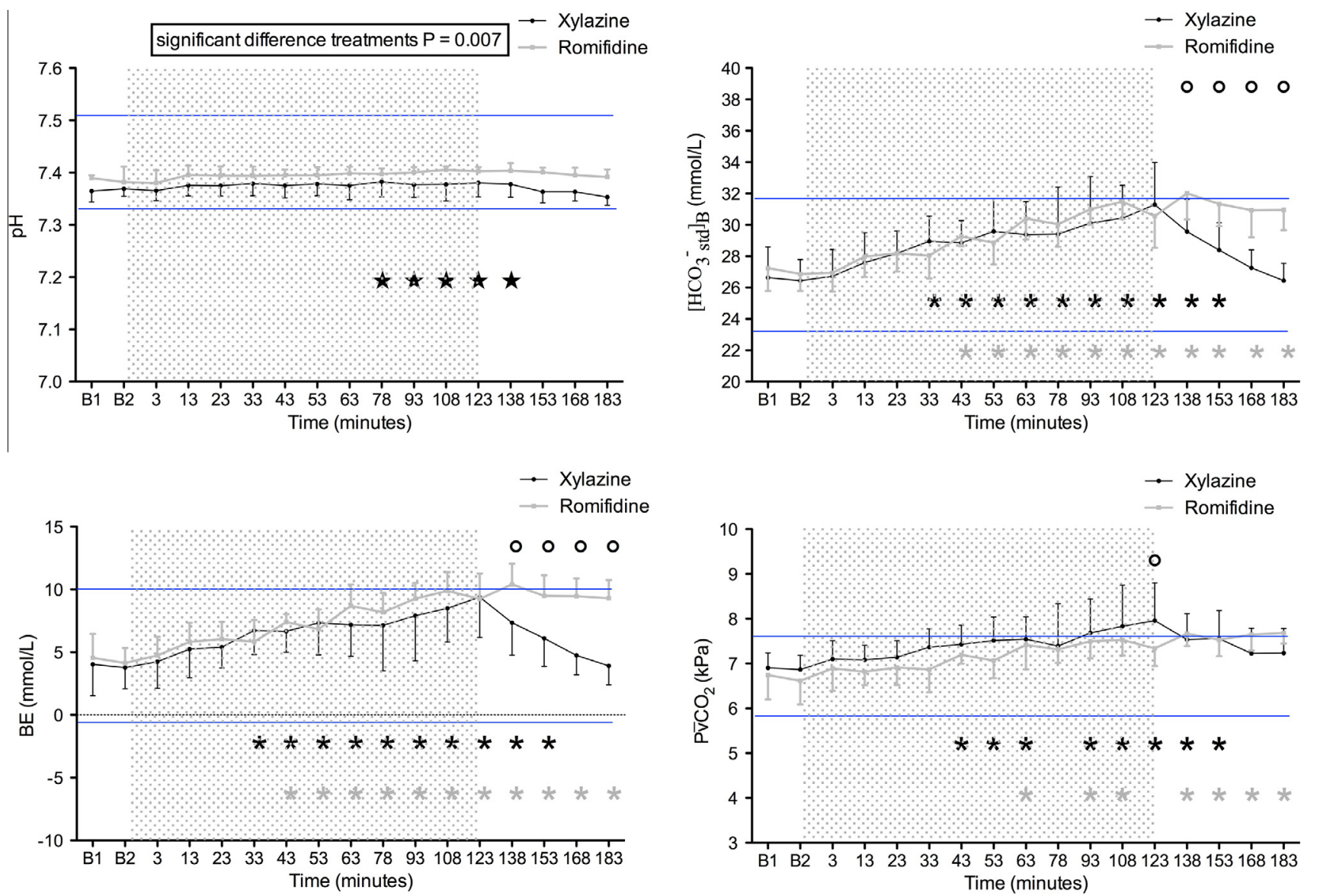

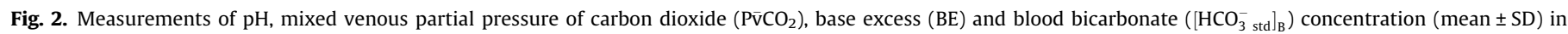

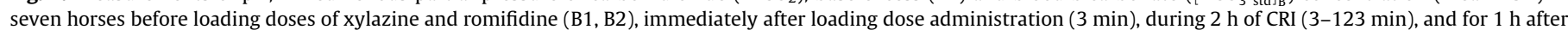

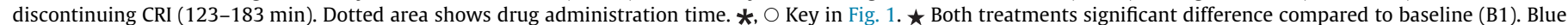
lines represent (mean $\pm 2 \mathrm{SD}$ ) values obtained in 15 healthy horses.

observed with xylazine compared to romifidine at the end of CRI (123 min). After discontinuing CRI, with xylazine the AG increased rapidly, leading to a higher AG compared to romifidine at $183 \mathrm{~min}$.

\section{Discussion}

The results of this study indicate that both xylazine and romifidine significantly alter $[\mathrm{Glu}]_{\mathrm{B}}$, electrolyte concentrations and acid base balance when administered as a bolus followed by a CRI during $2 \mathrm{~h}$ in healthy horses.

An increase in $[\mathrm{Glu}]_{B}$ has been described in the horse after administration of single doses of different alpha 2 -adrenergic agonists (England and Clarke, 1996) and during detomidine CRI combined with buprenorphine (van Dijk et al., 2003). However, to our knowledge this is the first time effects on [Glu $]_{B}$ were studied during CRIs of alpha ${ }_{2}$-adrenergic agonists as sole agents in horses.

Postsynaptic alpha ${ }_{2}$-adrenergic receptors of the pancreatic $\beta$-cells are involved in insulin regulation (Ruohonen et al., 2012) and probably play an important role in the hyperglycaemic effect of alpha ${ }_{2}$-adrenergic agonists. However, other authors have suggested that the effects of alpha ${ }_{2}$-adrenergic agonist on glycaemic response are not only due to actions mediated by alpha adrener- $_{2}$ gic receptors (Ambrisko and Hikasa, 2002; Kanda and Hikasa, 2008). Other sites of action (e.g. hepatic tissue) and involvement of other receptors such as alpha $a_{1}$-adrenergic receptors and imidazoline receptors have been proposed (Ambrisko and Hikasa, 2002; Kanda and Hikasa, 2008).
In the present study, the increase in $[\mathrm{Glu}]_{\mathrm{B}}$ was more pronounced with romifidine compared to xylazine. Differences in hyperglycaemic response between different alpha $_{2}$-adrenergic agonists have already been described in dogs and cats (Ambrisko and Hikasa, 2002; Kanda and Hikasa, 2008). It has been hypothesised that the high alpha ${ }_{2}$-adrenergic selectivity of medetomidine compared to other alpha $_{2}$-adrenergic agonists is most likely responsible for its less pronounced (i.e. non-significant) effect on plasma glucose concentration in dogs (Burton et al., 1997). However, this is not in agreement with the results of the present study where romifidine, the more alpha ${ }_{2}$-selective drug, produced a more pronounced effect on hyperglycaemia compared to xylazine.

In human medicine, hyperglycaemia from any cause is associated with worse outcomes in proportion to the elevations in $[\mathrm{Glu}]_{\mathrm{B}}$ (Klonoff, 2011). In the present study, [Glu $]_{B}$ appeared to increase continuously during CRI and to decrease only once alpha ${ }_{2}$-adrenergic agonists were discontinued. Therefore, even higher $[\mathrm{Glu}]_{B}$ can be expected during more prolonged infusions. Absolute values of the present study should be interpreted with caution, as some horses received repeated boli of $5 \%$ glucose solution for cardiac output measurements. In two horses, normal saline was used instead, to see if changes in $[\mathrm{Glu}]_{\mathrm{B}}$ were only due to the glucose solution used for cardiac output measurement. In these two horses not receiving $5 \%$ glucose solution, an increase in $[\mathrm{Glu}]_{\mathrm{B}}$ was also observed, and the increase was larger with romifidine compared to xylazine (Fig. 1). Also, the fact that $[\mathrm{Glu}]_{\mathrm{B}}$ decreased after discontinuing alpha $a_{2}$-adrenergic agonists despite continuing cardiac output measurements indicates that the increase observed during 

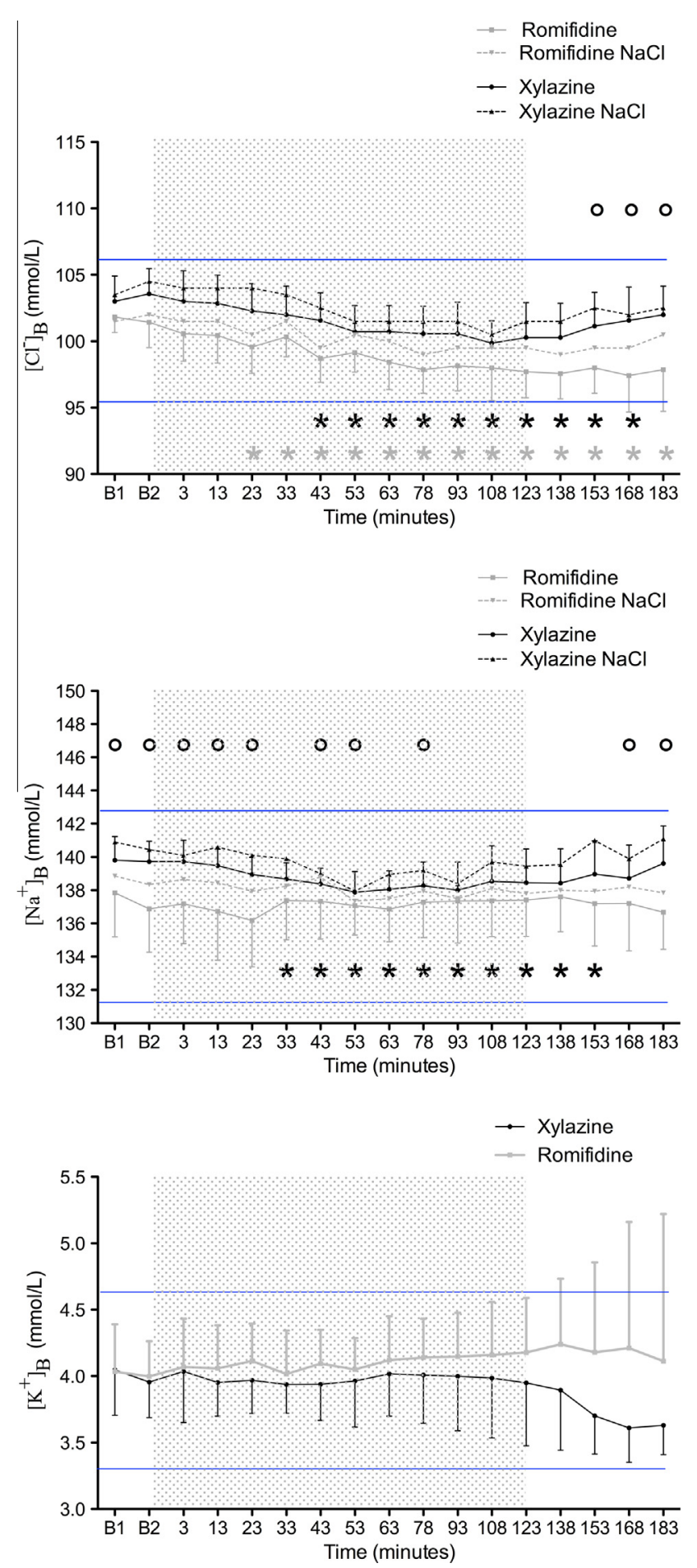

Fig. 3. Measurements of blood sodium $\left[\mathrm{Na}^{+}\right]_{\mathrm{B}}$, chloride $\left[\mathrm{Cl}^{-}\right]_{\mathrm{B}}$, and $\left[\mathrm{K}^{+}\right]_{\mathrm{B}}$ concentrations (mean $\pm S D$ ) before loading doses of xylazine and romifidine (B1, B2), immediately after loading dose administration ( $3 \mathrm{~min}$ ), during $2 \mathrm{~h}$ of CRI (3-123 min), and for $1 \mathrm{~h}$ after discontinuing CRI (123-183 min). Five horses received $5 \%$ glucose solution (continuous lines) and two received $0.9 \% \mathrm{NaCl}$ (dashed lines) for cardiac output measurements. Dotted area shows drug administration time. $*$, $\bigcirc$ Key in Fig. 1. Blue lines represent (mean \pm 2 SD) values obtained in 15 healthy horses.

alpha $_{2}$-adrenergic agonist CRI was not only due to $5 \%$ glucose administration.

Blood electrolyte concentrations were studied during $3 \mathrm{~h}$ of medetomidine-morphine CRI and no significant changes were seen in $\mathrm{Na}^{+}, \mathrm{K}^{+}$and $\mathrm{Cl}^{-}$(Solano et al., 2009). In the present study,
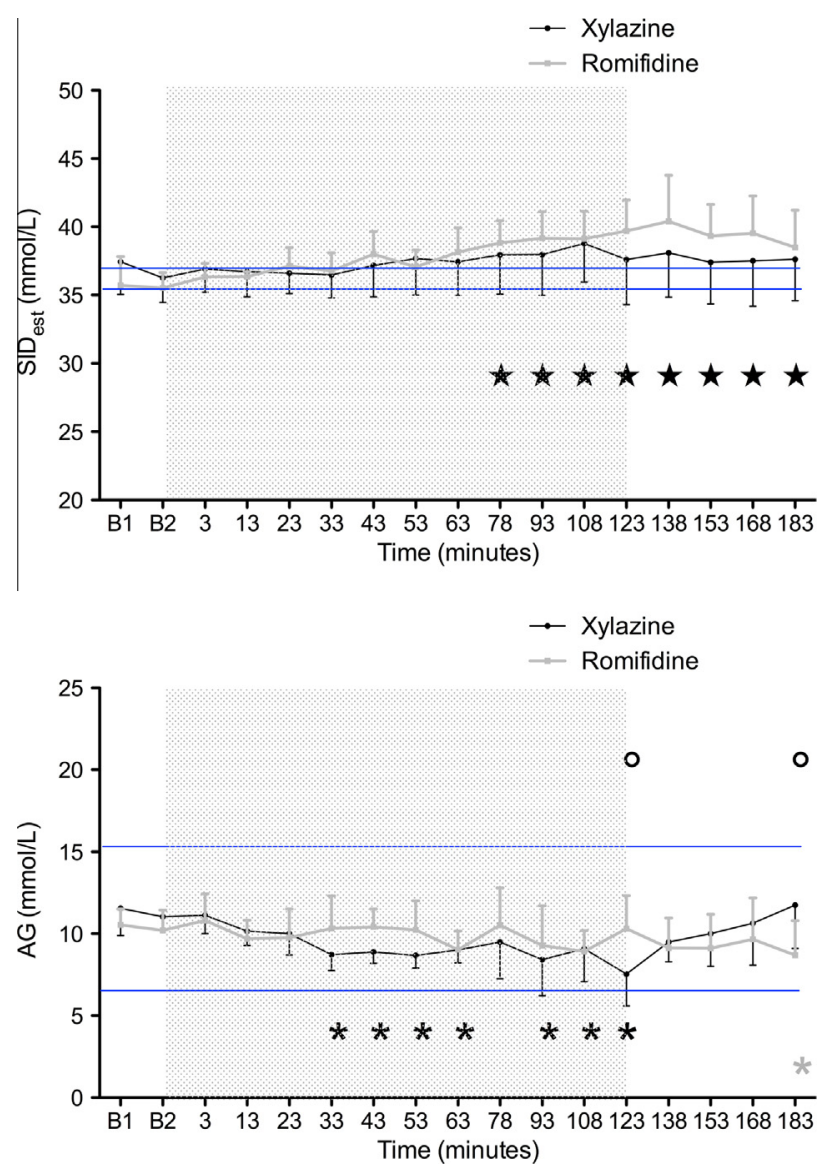

Fig. 4. Estimated strong ion difference $\left(\mathrm{SID}_{\mathrm{est}}\right)$ and anion gap $(A G)$ (mean $\pm \mathrm{SD}$ ) measured in seven horses before loading doses of xylazine and romifidine (B1, B2), immediately after loading dose administration ( $3 \mathrm{~min}$ ), during $2 \mathrm{~h}$ of CRI (3$123 \mathrm{~min}$ ), and for $1 \mathrm{~h}$ after discontinuing CRI (123-183 min). Dotted area shows drug administration time. $\star$, $\bigcirc$ Key in Fig. $1 . \star$ Both treatments significant difference compared to baseline (B1) Blue lines represent (mean \pm 2 SD) values obtained in 15 healthy horses.

a continuous and significant decrease in $\left[\mathrm{Cl}^{-}\right]_{\mathrm{B}}$ and increase in SID $_{\text {est }}$ was observed during both CRIs. However, the decrease in $\left[\mathrm{Na}^{+}\right]_{\mathrm{B}}$ was only significant with xylazine. The $\mathrm{SID}_{\text {est }}$ can increase due to an increase in plasma $\mathrm{Na}^{+}$concentration, a decrease in $\mathrm{Cl}^{-}$ concentration, or a decrease in plasma free water (commonly dehydration) (Autran de Morais and Constable, 2012). Dehydration and hypernatremia are unlikely, since a decrease rather than an increase in $\left[\mathrm{Na}^{+}\right]_{\mathrm{B}}$ concentration was observed in the present study. Therefore, the increase in $\operatorname{SID}_{\text {est }}$ is mostly attributed to the decrease in $\left[\mathrm{Cl}^{-}\right]_{\mathrm{B}}$. A decrease in serum $\left[\mathrm{Cl}^{-}\right]_{\mathrm{B}}$ has not been reported after alpha $_{2}$-adrenergic agonist administration before. However, an increased excretion of $\mathrm{Cl}^{-}$was observed after xylazine bolus administration in horses (Trim and Hanson, 1986).

Effects of alpha $a_{2}$-adrenergic agonists on $\mathrm{Cl}^{-}$transport have been demonstrated on human cystic fibrosis epithelial and colonic cell lines (Holliday et al., 1997; Norez et al., 2008). However, urinary electrolyte concentrations and fractional excretion of electrolytes in the urine were not investigated in the present study and the exact mechanism leading to the observed electrolyte changes in horses cannot be elucidated. A compensatory hypochloraemic alkalosis in response to the increased $\mathrm{P}_{\bar{v}} \mathrm{CO}_{2}$ is unlikely, as there was a simultaneous increase in $\mathrm{pH}$, which would mean that overcompensation had occurred, and this is improbable. Nevertheless, it is interesting that this is the first time that a decrease in $\left[\mathrm{Cl}^{-}\right]_{\mathrm{B}}$ has been described related to alpha ${ }_{2}$-adrenergic agonists. 
Contrary to our results observed with xylazine, no decrease or even a significant increase in serum $\mathrm{Na}^{+}$concentration has been observed in other studies using different single doses of alpha $2_{2}$ adrenergic agonists (Thurmon et al., 1984; Trim and Hanson, 1986; Gasthuys et al., 1993; Kullmann et al., 2011; Wojtasiak-Wypart et al., 2012). Nevertheless, an increased $\mathrm{Na}^{+}$excretion in urine has been described for horses after romifidine (Gasthuys et al., 1993). No changes in $\left[\mathrm{K}^{+}\right]_{\mathrm{B}}$ were observed in the present study. However, effects on serum concentration and urinary excretion of $\mathrm{K}^{+}$have been described after single doses of xylazine and romifidine (Trim and Hanson, 1986; Wojtasiak-Wypart et al., 2012).

In our study, a decrease in AG was observed, although with romifidine, the decrease was only significant $1 \mathrm{~h}$ after discontinuing CRI. Hypoalbuminaemia is considered the only important cause for a decrease in AG (Autran de Morais and Leisewitz, 2012), although an accumulation of unmeasured cations (e.g., hypercalcaemia, hyperkalaemia and hypermagnesaemia) should be considered as well (Rennke and Denker, 2007). In the present study, there were no significant changes in $\left[\mathrm{K}^{+}\right]_{\mathrm{B}}$ and a decrease, rather than an increase in $\mathrm{Ca}^{2+}$ has been previously reported after romifidine administration (Wojtasiak-Wypart et al., 2012). However, a decrease in total plasma solids has been described during detomidine CRI (Daunt et al., 1993) and a decrease in total proteins during medetomidine/morphine CRI (Solano et al., 2009). Unfortunately, plasma proteins, albumin, $\mathrm{Ca}^{2+}$ and $\mathrm{Mg}^{2+}$ were not measured in the present study.

A significant increase in $\mathrm{pH}, \mathrm{BE}_{\mathrm{ecf}},\left[\mathrm{HCO}_{3}^{-} \mathrm{std}_{\mathrm{B}}\right.$, and $\mathrm{PvCO}_{2}$ was observed during both treatments. However $\mathrm{pH}$ values remained within physiologically normal limits. An increase in $\mathrm{pH}$ has not been reported previously after single doses of the different alpha ${ }_{2}$ adrenergic agonists (Clarke et al., 1991; Bueno et al., 1999; Yamashita et al., 2000; Freeman et al., 2002; Bettschart-Wolfensberger et al., 2005) or during CRI of medetomidine and detomidine (Daunt et al., 1993; Bettschart-Wolfensberger et al., 1999; van Dijk et al., 2003) in horses. Conversely, a decrease in $\mathrm{pH}$ in face of an increase in $\mathrm{HCO}_{3}^{-}$was reported during a CRI of medetomidine-morphine (Solano et al., 2009). However, the horses of Solano et al. (2009) underwent laparoscopy with insufflation of carbon dioxide, which was accompanied by a significant increase in $\mathrm{PaCO}_{2}$.

In this study, the increase in $\mathrm{pH}$ observed in face of an increase in $\mathrm{P} \overline{\mathrm{v}} \mathrm{CO}_{2}$, associated with an increase in $\mathrm{BE}$ and $\mathrm{SID}_{\text {est }}$ and a decrease in AG, were indicative of metabolic alkalosis. As already mentioned before, the increase in SID $_{\text {est }}$ was probably due to a decrease in $\left[\mathrm{Cl}^{-}\right]_{\mathrm{B}}$. Therefore, hypochloraemic metabolic alkalosis was suspected, resulting from an increase in blood $\left[\mathrm{HCO}_{3}^{-} \mathrm{std}\right]_{\mathrm{B}}$ secondary to loss of $\mathrm{Cl}^{-}$from the body. A significant increase in $\left[\mathrm{HCO}_{3}^{-} \mathrm{std}\right]_{\mathrm{B}}$ was observed for both alpha ${ }_{2}$-adrenergic agonists. Similar effects on $\mathrm{HCO}_{3}^{-}$and $\mathrm{BE}$ have been observed after single doses of romifidine (Freeman et al., 2002; Wojtasiak-Wypart et al., 2012) or during medetomidine or detomidine CRI (Daunt et al., 1993; Bettschart-Wolfensberger et al., 1999; Solano et al., 2009) in horses. Unfortunately blood lactate was not measured in the present study. However, based on the rather elevated $\mathrm{BE}$ and $\mathrm{pH}$ we do not expect an important increase in lactate. This would coincide with previous studies reporting no changes in blood lactate after single doses or CRIs of alpha ${ }_{2}$-adrenergic agonists in horses (Solano et al., 2009; Kullmann et al., 2011).

The significant differences seen between the two alpha ${ }_{2}$-adrenergic agonists in the present study might be attributed to the specificity or selectivity for different subtypes of alpha ${ }_{2}$-adrenergic receptors or collateral effects on other receptors like imidazoline or alpha $_{1}$-adrenergic receptors, or due to a complex interaction of different mechanisms. The difference might also be dose-dependent. However, the two protocols used in the present study provided the same depth of sedation during CRI, as assessed by the head position in relation to the ground in undisturbed healthy horses
(Ringer et al., 2013b). The more prolonged effect of romifidine compared to xylazine after discontinuing drug administration is not surprising, as a prolonged effect of romifidine compared to xylazine has already been shown for sedation and cardiovascular effects (Ringer et al., 2013a,b).

The main limitation of the present study is the use of fluid boli for cardiac output measurements of a concomitant study. This could have had an effect on our absolute values, however not on the comparison between the two treatments, as each individual horse received the same fluid during both treatments. Also the fact that variables tended to normalise after discontinuing alpha $a_{2}$ adrenergic agonists despite continuing cardiac output measurements indicates, that changes were unlikely only due to fluid boli.

The clinical importance of the changes we observed remains to be investigated. However, fact is that with both alpha $a_{2}$-adrenergic agonists mean values of several variables were outside the mean \pm 2 SD of the reference values obtained from 15 healthy horses. With both alpha ${ }_{2}$-adrenergic agonists the changes observed were increasing with duration of CRI. Therefore, aggravation of the effects should be expected during more prolonged infusion. The induced changes should probably also be considered in critically ill patients with pre-existing disturbances in $[\mathrm{Glu}]_{\mathrm{B}}$, electrolyte, and acid-base balance, where further alterations in biochemical variables might be crucial. This is critical, as the use of alpha ${ }_{2}$-adrenergic agonist CRIs to provide sedation, anxiolysis and analgesia is becoming more and more popular in human and small animal ICUs (Posner and Burns, 2009; Tan and Ho, 2010; Hoy and Keating, 2011), and probably in the future also in equine intensive care patients.

However, extrapolation of the present results to different populations should be done with caution, since the effects might depend on the alpha ${ }_{2}$-adrenergic agonist used, its dose, the duration of administration, the species and the underlying condition and metabolic status of the animal. Therefore, further studies using the different alpha 2 -adrenergic agonist as a CRI in the different species and under different conditions are recommended to elucidate the relevance of alpha $a_{2}$-adrenergic agonist-induced metabolic changes in clinical patients.

\section{Conclusions}

Xylazine and romifidine administered as a CRI had significant effects on $[\mathrm{Glu}]_{\mathrm{B}}$, electrolyte concentrations, and acid-base status in horses. Changes become progressively more prominent during CRI, and should be considered in patients receiving prolonged alpha $_{2}$-adrenergic agonist infusions.

\section{Conflict of interest statement}

None of the authors of this paper has a financial or personal relationship with other people or organisations that could inappropriately influence or bias the content of the paper.

\section{Acknowledgements}

The authors would like to thank the Forschungskredit of the University of Zurich and the Stiftung Forschung für das Pferd for financial support. We further acknowledge Siemens Healthcare Diagnostics France for providing the point-of-care blood gas system (Rapidpoint 400) including reagent kits and technical support, and the companies Dr. E. Graeub AG and Boehringer Ingelheim France for providing the xylazine and romifidine for this study.

Parts of the results have been published as a poster presentation at the spring meeting of the Association of Veterinary Anaesthetists in Bari, Italy, 2011. 


\section{References}

Ambrisko, T.D., Hikasa, Y., 2002. Neurohormonal and metabolic effects of medetomidine compared with xylazine in beagle dogs. Canadian Journal of Veterinary Research 66, 42-49.

Autran de Morais, H., Constable, P.D., 2012. Strong ion approach to acid-base disorders. In: DiBartola, S.P. (Ed.), Fluid, Electrolyte, and Acid-Base Disorders in Small Animal Practice. Elsevier Saunders, St. Louis, Missouri, pp. 316-329.

Autran de Morais, H., Leisewitz, A.L., 2012. Mixed acid-base disorders. In: DiBartola, S.P. (Ed.), Fluid, Electrolyte, and Acid-Base Disorders in Small Animal Practice, Fourth Ed. Elsevier Saunders, St. Louis, MO, USA, pp. 302-315.

Bettschart-Wolfensberger, R., Bettschart, R.W., Vainio, O., Marlin, D., 1999. Cardiopulmonary effects of a two hour medetomidine infusion and its antagonism by atipamezole in horses and ponies. Journal of Veterinary Anaesthesia 26, 8-12.

Bettschart-Wolfensberger, R., Freeman, S.L., Bowen, I.M., Aliabadi, F.S., Weller, R., Huhtinen, M., Clarke, K.W., 2005. Cardiopulmonary effects and pharmacokinetics of i.v. dexmedetomidine in ponies. Equine Veterinary Journal 37, 60-64.

Bueno, A.C., Cornick-Seahorn, J., Seahorn, T.L., Hosgood, G., Moore, R.M., 1999 Cardiopulmonary and sedative effects of intravenous administration of low doses of medetomidine and xylazine to adult horses. American Journal of Veterinary Research 60, 1371-1376.

Burton, S.A., Lemke, K.A., Ihle, S.L., Mackenzie, A.L., 1997. Effects of medetomidine on serum insulin and plasma glucose concentrations in clinically normal dogs. American Journal of Veterinary Research 58, 1440-1442.

Clarke, K.W., England, G.C.W., Goossens, L., 1991. Sedative and cardiovascular effects of romifidine, alone and in combination with butorphanol, in the horse. Journal of Veterinary Anaesthesia 18, 25-29.

Dart, C.M., 1999. Advantages and disadvantages of using alpha-2 agonists in veterinary practice. Australian Veterinary Journal 77, 720-721.

Daunt, D.A., Dunlop, C.I., Chapman, P.L., Shafer, S.L., Ruskoaho, H., Vakkuri, O., Hodgson, D.S., Tyler, L.M., Maze, M., 1993. Cardiopulmonary and behavioral responses to computer-driven infusion of detomidine in standing horses. American Journal of Veterinary Research 54, 2075-2082.

England, G.C., Clarke, K.W., 1996. Alpha 2 adrenoceptor agonists in the horse - A review. British Veterinary Journal 152, 641-657.

Freeman, S.L., Bowen, I.M., Bettschart-Wolfensberger, R., Alibhai, H.I., England, G.C., 2002. Cardiovascular effects of romifidine in the standing horse. Research in Veterinary Science 72, 123-129.

Gasthuys, F., De Moor, A., Goossens, L., 1993. Quantitative study of the diuresis induced by romifidine in the mare. Journal of Veterinary Anaesthesia 20, 47-48.

Holliday, N.D., Tough, I.R., Cox, H.M., 1997. Inhibition of cyclic AMP-dependent chloride secretion by PP receptors and alpha 2-adrenoceptors in a human colonic epithelial cell line. Naunyn Schmiedebergs Archives of Pharmacology $355,183-189$.

Hoy, S.M., Keating, G.M., 2011. Dexmedetomidine: A review of its use for sedation in mechanically ventilated patients in an intensive care setting and for procedural sedation. Drugs 71, 1481-1501.

Kanda, T., Hikasa, Y., 2008. Neurohormonal and metabolic effects of medetomidine compared with xylazine in healthy cats. Canadian Journal of Veterinary Research 72, 278-286.

Klonoff, D.C., 2011. Intensive insulin therapy in critically ill hospitalized patients: Making it safe and effective. Journal of Diabetes Science and Technology 5, 755767.

Kullmann, A., Sanz, M., Fosgate, G., Saulez, M., Page, P., Rioja, E., 2011. Effects of xylazine, romifidine or detomidine on hematology, biochemistry and splenic size in healthy horses. In: Proceedings of the 17th International Veterinary Emergency \& Critical Care Symposium, Nashville, TN, USA, p. s16.

Lamont, L., Burton, S., Caines, D., Masaoud, E., Troncy, E., 2012. Effects of 2 different medetomidine infusion rates on selected neurohormonal and metabolic parameters in dogs. Canadian Journal of Veterinary Research 76, 143-148.
Muir, W.W., 2009. Anxiolytics, nonopioid sedative-analgesics, and opioid analgesics. In: Muir, W.W., Hubbell, J.A.E. (Eds.), Equine Anesthesia: Monitoring and Emergency Therapy, Second Ed. Saunders Elsevier, St. Louis, MO, USA, pp. 185-209.

Murahata, Y., Hikasa, Y., 2011. Diuretic effects of medetomidine compared with xylazine in healthy cats. In: Proceedings of the 10th IVECCS Congress, Utrecht, Netherlands, p. 12.

Murrell, J.C., Hellebrekers, L.J., 2005. Medetomidine and dexmedetomidine: A review of cardiovascular effects and antinociceptive properties in the dog. Veterinary Anaesthesia and Analgesia 32, 117-127.

Norez, C., Vandebrouck, C., Antigny, F., Dannhoffer, L., Blondel, M., Becq, F., 2008 Guanabenz, an alpha2-selective adrenergic agonist, activates $\mathrm{Ca}^{2+}$-dependent chloride currents in cystic fibrosis human airway epithelial cells. European Journal of Pharmacology 592, 33-40.

Posner, L.P., Burns, P., 2009. Sedative agents. In: Riviere, J.E., Papich, M.G. (Eds.) Veterinary Pharmacology and Therapeutics, Ninth Ed. Wiley-Blackwell, Ames, Iowa, USA, pp. 337-380.

Rennke, H.G., Denker, B.M., 2007. Metabolic acidosis. In: Rennke, H.G., Denker, B.M. (Eds.), Renal Pathophysiology: The Essentials, Second Ed. Lippincott Williams \& Wilkins, Baltimore, MD, USA, p. 164.

Ringer, S.K., 2012. Chemical restraint for standing surgery. In: Stick, A. (Ed.), Equine Surgery, Fourth Ed. Elsevier Saunders, St. Louis, MO, USA, pp. 253-262.

Ringer, S.K., Schwarzwald, C.C., Portier, K.G., Ritter, A., Bettschart-Wolfensberger, R. 2013a. Effects on cardiopulmonary function and oxygen delivery of doses of romifidine and xylazine followed by constant rate infusions in standing horses. The Veterinary Journal 195, 228-234.

Ringer, S.K., Portier, K., Torgerson, P.R., Castagno, R., Bettschart-Wolfensberger, R. 2013b. The effects of a loading dose followed by constant rate infusion of xylazine compared with romifidine on sedation, ataxia and response to stimuli in horses. Veterinary Anaesthesia and Analgesia 40, 157-165.

Ruohonen, S.T., Ruohonen, S., Gilsbach, R., Savontaus, E., Scheinin, M., Hein, L., 2012. Involvement of alpha2-adrenoceptor subtypes A and C in glucose homeostasis and adrenaline-induced hyperglycaemia. Neuroendocrinology 96, 51-59.

Solano, A.M., Valverde, A., Desrochers, A., Nykamp, S., Boure, L.P., 2009. Behavioural and cardiorespiratory effects of a constant rate infusion of medetomidine and morphine for sedation during standing laparoscopy in horses. Equine Veterinary Journal 41, 153-159.

Talukder, M.H., Hikasa, Y., 2009. Diuretic effects of medetomidine compared with xylazine in healthy dogs. Canadian Journal of Veterinary Research 73, 224-236.

Tan, J.A., Ho, K.M., 2010. Use of dexmedetomidine as a sedative and analgesic agent in critically ill adult patients: A meta-analysis. Intensive Care Medicine 36, 926 939.

Thurmon, J.C., Steffey, E.P., Zinkl, J.G., Woliner, M., Howland Jr., D., 1984. Xylazine causes transient dose-related hyperglycemia and increased urine volumes in mares. American Journal of Veterinary Research 45, 224-227.

Trim, C.M., Hanson, R.R., 1986. Effects of xylazine on renal function and plasma glucose in ponies. Veterinary Record 118, 65-67.

van Dijk, P., Lankveld, D.P., Rijkenhuizen, A.B., Jonker, F.H., 2003. Hormonal metabolic and physiological effects of laparoscopic surgery using a detomidinebuprenorphine combination in standing horses. Veterinary Anaesthesia and Analgesia 30, 72-80.

Wojtasiak-Wypart, M., Soma, L.R., Rudy, J.A., Uboh, C.E., Boston, R.C., Driessen, B. 2012. Pharmacokinetic profile and pharmacodynamic effects of romifidine hydrochloride in the horse. Journal of Veterinary Pharmacology and Therapeutics 35, 478-488.

Yamashita, K., Tsubakishita, S., Futaok, S., Ueda, I., Hamaguchi, H., Seno, T., Katoh, S., Izumisawa, Y., Kotani, T., Muir, W.W., 2000. Cardiovascular effects of medetomidine, detomidine and xylazine in horses. Journal of Veterinary Medical Science 62, 1025-1032. 